\title{
Fintech: Really a buzzword, at Embryonic Stage or a burgeoning Industry? with special reference to India
}

\author{
Miss Shreya Arora ${ }^{*}$, Prof.(Dr.) Pankaj Madan ${ }^{1}$ \\ ${ }^{*}$ Research Scholar, Gurukul (deemed to be University), Haridwar \\ ${ }^{1}$ Head and Dean, FET, Gurukul (deemed to be University), Haridwar \\ *19519003@gkv.ac.in \\ ${ }^{2}$ pankaj.madan@gkv.ac.in
}

*Corresponding Author

\begin{abstract}
With increasing average deal size, funding rounds closing in record time and half a dozen startups entering unicorn club a week, Indian startups are in momentum in India with Fintech occupying a significant space among them. Government schemes, customers' expectations, cashless economy, digitalization, globalization, innovation etc. are some of the determinants due to which Fin tech has emerged as one of the most investment attractive destination. Traditional financial institutions are partnering with the Fin tech firms in order to survive as well as to compete. Present paper is an attempt to peep into such reasons for the growth of this Fin tech sector in various segments along with its future avenues. The figures mentioned are based searched articles in magazines, newspapers and published reports on websites etc. It has been concluded that India has a high potential as well as opportunity in the Fintech sector specially in the payment segment as consumers are becoming smarter day by day which in turn forcing and motivating the industries for the innovation in their services to remain in the race.
\end{abstract}

Keywords: FinTech, Digital Wallets, Insurtech, Regtech, Blockchain

\section{Introduction}

\subsection{Coinage of the Fintech}

In common parlance, Fintech is the combination of two words i.e. Finance (here Financial services) and tech which means technology. So, when financial services are provided with the help of technology to the customers, it becomes very easy, flexible as well as convenient to access and handle without any involvement of financial institutions such as banks [17]. Many counties are ahead in Fintech sectors but globally India has the highest rank if we talk about the Fintech adoption rate with China. The digital payments that were valued at $\$ 65 \mathrm{bn}$ in the year 2019, are expected to grow at a CAGR of $20 \%$ by 
2023(https://investindia.gov.in)[12]. Traditional financial institutions are undergoing many innovations. As per the reports of the "Fintech Disruptor Reports (2017)" The financial institutions have estimated that $1 / 3^{\text {rd }}$ of their revenues are risky from the innovations in Fintech To be competitive many traditional financial institutions are thinking of partnership with the Fintech firms to attract more and more customers.KMPG,2015, reports say that technology like AI \& cryptocurrencies has changed the way of asset management, innovatively providing the technology, secondly, they focus on the customer needs, insurance services, banking services, etc. According to the reports of the EY Fintech Adoption Index(2017), globally, Fintech institutions have 2 features namely- first to apply an innovation India has surpassed China in Asia's top Fintech funding target market. Indian Fintech startups have are having \$286 mn investments across 29 deals, which is $\$ 192.1 \mathrm{mn}$ across 29 deals in the case of China in the first quarter of 2019. [22] concept of the cashless economy has transformed the way of thinking as well as transacting among the Indian citizens. They would prefer to transact over the internet for it is a very convenient way to handle the transactions. Often people deal with transactions related to Gold, loans, investments, etc. These are some reasons for the emergence of what we called today Fintech, Fintech works in various branches such as blockchain tech., cybersecurity, Robo- advisors, cryptocurrencies, etc. (RBI, n.d.)when continuous growth in information technology results in technical innovations in the field of the financial sector, it leads to the birth of Fintech. Any innovation which tends to change the existing business processes, may it be the usage of financial services or delivery process.[19] When any kind of technological change occurs in the following three categories namely, allocation, transfer as well as raising of capital, then it gives a birth to fintech.[13].

\subsection{Journey/Phases of Fintech}

As per the reports of "Banking on the future ",2017, there are the three ages of Fintech.[19]

1.2.1Fintech 1.0(1866-1967): This was the first phase of Fintech when there was an advent of ATM. This was the period in which financial globalization was taking place in the form of a combination of finance and technology.

1.2.2. Fintech 2.0(1967-2008): As per the reports of "Banking on the future ",2017, there are the three ages of Fintech. Here, the traditional financial services providers were using the technology to provide financial services to their customers. So, up to this period, Fintech was in the limited hands. Electronic payment and clearing system, ATMs, online banking, they all came during this phase.

1.2.3Fintech 3.0(2008-present): As per the reports of "Banking on the future ",2017, there are the three ages of Fintech "Necessity is the mother of invention". This is true when one thinks about the financial crisis of 2008 that has given birth to many startups. All these were focused on the provision of customized financial services to the users with the help of technology.

\subsection{How the concept of Fintech Evolved in India}

The banking industry in India has been liberalized in the late 1990s with the advent of tech-savvy banks. Slow growth had been witnessed two decades from 1991 in the technological innovations in the financial services. Fintech was booming globally likewise it started its journey in the field of consumer-facing offerings in India and in 2005 came up with the first such offering with the banking correspondent(BC) model. FinoPayTech \& Eko India were the first to grab this advantage and build their services 
using the BC model. 2010 was the year from which many fintech startups have been arising in the different sectors such as lending, management of personal finance, management of investments, e payments startups, mobile wallets, etc. Indian Fintech sector has seen development not only in the field of startups and investments but also many govt. as well as regulatory bodies have taken many steps to innovate their services such as the launch of Universal Payment Interface. Major e-commerce players Flipkart and Snapdeal have partnered with Yes bank and axis bank to introduce UPI in the offerings Of their mobile payments. Waves of Fintech growth has not stopped here as banks had started making partnership with the fintech startups. Many banks have taken initiative for the improvements in their digital financial infrastructure :

1. To enhance NFC payments in India, ICICI Bank had launched a contactless mobile payment system.

2."Invoice to payment" feature that has been presented by Axis Bank, provides end-toend digital invoicing and payment solutions.

3.Customers can open their accounts digitally with the help of PAN \& Aadhaar cards using the mobile bank feature introduced by DBS.

4. *99\# application provides the basic services to the customers like balance inquiry, $t / f$ of funds as well as mini statements even without the internet connectivity. This application has been launched by Union Bank in partnership with NPCI.

\subsection{Fintech segmentation}

According to the reports of the EY Fintech Adoption Index(2017) In India, the Fintech industry has been segmented into 4 major branches such as WealthTech, Payments, Insure Tech and Lending. When innovative technology has been applied in the field of financial services, it is known as Fintech. Schindler has categorized the Fintech innovations into the following categories: online marketplace lending which is commonly known as p2p lending, equity crowdfunding, Distributed ledger technology application in financial services, Robo-advice machine learning and its financial applications. Fintech has been segmented based on services they provide by Lee \& Jae Shin such as : payments, wealth management, capital market, management of wealth, crowdfunding, Insurance fintech, lending [23]. [2]Wealthtech, payment, lending, insurtech blockchain, etc are some of the major subsegments which have been gaining popularity .Many factors become the reason for the innovation in the financial services sector. Globalization, less intervention in the working of financial markets, high competitiveness, advancement in the technology to name a few. Fintech in the banking sector has changed the work perform by traditional banks. Now banks are partnering with the fintech companies to reduce competitiveness and simultaneously to gain the benefit of technology. Smart devices are being used along with debit/credit cards which further became the reason for the growth of Fintech. The young generation as well as high-class people are considered as the early adopters of Fintech services as they want to depend on the traditional ways of banking which are boring and time-consuming. There is a huge growth potential for the Fintech sector in India. Government initiatives such as Adhaar linking, Jan Dhan Yojana, Cashless Digital Transactions, etc. have fueled this Fintech sector which will be expected to flourish more in the coming future[18]. Many fintech startups are very much successful in the payment segment as India is moving towards a cashless economy very fast. Although there are many challenges related to fintech still India has the potential to grow further in this industry as the government is supporting the fintech activities in one or the other ways through various schemes moreover India is a treasure of huge entrepreneurship skills. Lack of awareness and proper knowledge about the availability and the usage of the 
services, preference, and trustworthiness over the traditional financial services are some of the barriers that are restraining the customers to enter fintech. [22]

\subsubsection{Financing}

[22]The lending and financing Process has been changed by the Fintech companies. There is no need to go to banks for borrowing. Two types of financing are :

\subsection{1(a)Crowdfunding}

There are different types of crowdfunding that are available for the users. two types have been explained hereunder.

\subsection{1(a.1) based on donation}

It is solely used for the charity purpose or the reason specific without any expectation in return.

\subsection{1(a.2) based on reward}

Generally, small businesses are funded by investors which wanted to fund the venture for non-monetary benefits through this kind of funding. greater the investment, greater will be his non-financial rewards such as free passes, gifts, etc for the events, etc. Crowdfunding is an innovative alternative to hold small investments in the form of equity and debt directly without the intermediation of the banks [24]. [2]Investment management is an art which is become easy, convenient as well as competitive in today's scenario due to the advent of technology. Crowdfunding method of raising the funds and that too over the internet has made the fund availability easy for the business entrepreneurs as they have the full details of the contributor's identity along with their past contributions, supportive campaigns, etc. Equity crowdfunding is the most disruptive of all the coming new Fintech platforms. As per the author, there are two types of crowding namely donation-based crowdfunding which includes both donations as well as reward-based crowdfunding and another one is investing crowdfunding.

\subsection{1(b)Crowd Investing}

[22] When the investment is made by the large group of people, in people or the business in the form of equity and debt over the internet, it is known as crowd investing.

\subsubsection{Lending}

[22] When the public becomes an investor and provides loans to the users in return for some amount of interest it is known as crowdlending. Many functions of banks have been performed with the help of this lending. [2]Fintech has played a significant role in P2P lending which is different from the traditional offline P2P model. The other name of $\mathrm{p} 2 \mathrm{p}$ lending is crowdlending which occurs among unrelated individuals. Such type of lending helps small, medium, and large businesses to avail themselves the required amount easily without any intermediary such as banks. The lender in the crowdlending invests in particular loan requests such as through Lending Club or Funding circle. This is different from the other types of crowd financing namely crowd equity (in which investors will have some share of another co.) reward-based or donation-based crowd financing. The profit of the Fintech firms is in the form of a fee charged on the credit by the lenders and not the difference between the deposits and the lending rates. As per the reports of Fintech in India by Swissnex India,2016, Family, community, offline lenders still are the major and prominent source of lending finance in India. Community lending is highly 
unregulated as well as most popular type of finance community lending is highly unregulated as well as most popular type of finance in India.

\subsubsection{Credit and factoring}

[22]Factoring is a process in which a seller can get loan money by selling their receivables. Nowadays, this process can run over the internet, where small and medium entrepreneurs can get a loan very easily in their accounts within a fraction of a time on a single click.

\subsubsection{Payments}

[22]Fintech allows the customers to transfer money to each other over the internet very easily, without any intervention of a bank. Earlier customers have to log in to their bank accounts to make any payment but now social media platforms allow such transfers, thanks to blockchain technology.[2]Plastic money like smart cards, debit/credit cards/, ATMs, etc. have paved the way for online purchasing which in turn has boosted e-commerce in the country. This has changed the way of working of the banks. Many innovations are there in the retail sector too such as mobile wallets, P2P mobile payments, etc. The payment sector has grown tremendously due to the entry of telecom operators and other payment services providers, thereby has become a highly competitive sector as well.

\subsubsection{Mobile wallet}

[2]It is another big innovation in the payment sector that has also revolutionized Fintech As per the reports of RBI, there exists around 21 million credit card users in India till 2015.4 types of $\mathrm{M}$ wallets are available such as closed wallets, semi-closed, open wallet, semi-open wallet. Paytm, Mobikwik, Airtel Money, M-Pesa, Free charge, etc are some of the most popular $\mathrm{M}$ wallets available.

As per the reports of Fintech in India by Swissnex India,2016,26 PPIs(prepaid payment instrument)licenses have been issued by RBI between 2009 \&2010. Mobile wallets \& prepaid cards are the two types of PPIs that are currently available in India. Paytm, Freecharge, MobiKwik, Citrus are some of the mobile wallets which are applicationbased stored value accounts available and are funded with the help of dr./cr. Cards or through net banking. These wallets are doing great jobs when it comes to mobile recharging, payment of bills, or e-commerce. They are exclusively doing tie-ups with various cab service providers, retail stores as well as with educational institutions, fuel stations, etc. to expand their reach towards the customers who are far behind from these services.

\subsubsection{Prepaid cards}

As per the reports of Fintech in India by Swissnex India,2016, Prepaid cards have been used for the management of expenses, remittances, book a train, etc. Oxygen, ItzCash, Suvidhaa, etc. are some of the startups behind the promotion of these prepaid cards to provide agent-assisted solutions to the less digitalized section of an economy.

\subsubsection{Payment banks}

Another popular innovation in the payment space is the emergence of payment banks. As per the reports of Fintech in India by Swissnex India,2016, Payment banks are the emerging hot segment in Fintech. [21] has thrown the light over the rise of digital wallets in India along with the expectations of its growth further in the coming future. 


\subsubsection{Wealthtech Fintech}

[22]Assets of high net worth individuals have been managed by Fintech along with the provision of financial as well as advisory services. Users can directly approach the wealth managers and can easily get their assets managed whether in the form of planned insurance, retirement, or any portfolio management without the help of any intermediary.

\subsubsection{Robo Advisors}

[22] They help the users in building a diversified portfolio. It helps those users who don't want to spend their money on the hiring of a financial advisor. The software provides automated investment advice based on an algorithm. [7]Betterment, which is a type of Robo advisor, makes use of algorithms to conduct investment-related decisions which are cost-effective and increases accessibility at the same time.

\subsubsection{Personal financial management(PFM):}

[22]It is just like digital budgeting which helps the users to be within their financial limits to avoid any kind of debt. Accounts from the different institutions get summed up in one place and the users can easily get an idea about their income, expenditures, savings, etc.

\subsubsection{Social Trading}

[22]Traders from all over the world share their experiences and knowledge over the social trading hubs. This information helps the investors to make good decisions for the investments without any intervention or broker etc.

\subsubsection{Insurtech}

[22]Fintech has reached this sector too. Insurance companies are trying to reach their customers directly through the different applications because they are much more flexible than traditional insurers.

\subsubsection{Regtech}

[7]This serves the financial services firms in complying with the industrial rules and regulations along with the KYC guidelines which in turn helps to protect against any fraudulent activity.

\subsubsection{Blockchain and cryptocurrency.}

[22]Blockchain keeps the customer's data secured and encrypted which is impossible to steal. It keeps the record of the transactions as a digital ledger. [21] Blockchain and big data are the two sides of the same coin. When they both unite to form a deadly combination to ripe a great fruit, hence they complement each other. Blockchain provides high-class security against any fraud or phishing activities while big data helps the financial institutions in exploring the needs of the consumers and provide them personalized solutions thereby gaining their confidence and raises their satisfaction which in turn increases the sales of the institutions.

\subsubsection{Other Fintech}

\subsubsection{2(a)Search engines and comparison sites}

[22]Here the search engines facilitate the users to compare various financial products and services offered by various service providers as per their requirements. 


\subsubsection{2(b)Technology, IT and Infrastructure}

[22] Here Fintech provides needful technical solutions to the different service providers.

\subsubsection{2(c)Financial Research and data analysis}

[2]Continuous research and the use of data analytics by the Fintech firms for credit scoring, management of risk, management of investments, customer acquisition, etc are some of the areas where fintech is innovating. According to the latest reports published by Invest India(National Investment Promotion \& Facilitation Agency These are the key segments of fintech namely, Digital payments, Digital lending Banktech, Wealthtech, Insurtech

\subsection{Growth determiners of Fintech}

[2] As per the author, there are some causes for the emergence of Fintech such as:

\subsubsection{Advancement of technology}

[2]Drastic increment in the users of mobile phones, growth in the social networks, development of big data analytics, etc has been considered as the main contributors in the emergence of the Fintech firms. New products and services are developing with the help of big data analytics which is cost-efficient, highly improvised, other benefits of big data analytics are better decision making, etc. As per the reports of "Banking on the future ",2017, Growth in computer processing power is inversely proportional to its cost to a consumer. This has been easily understood with the help of Moore's Law. Smartphones that have been manufactured using this high powered technology, are the main reason for the extensive growth of the fintech industry

\subsubsection{Change in the regulatory framework}

[2]Another favorable factor for the emergence of the Fintech firms is the change in the regulations and laws by the government after the financial crisis of 2008, which has been proved an ignited factor for the growth of the Fintech firms. There are many rules and regulations from which Fintech firms are exempted. there are the following growth drivers of the Fintech Industry.

\subsubsection{Consumer centric approach of the industries}

As per the reports of "Banking on the future ",2017, Digital economy co. are adopting this approach in which they take care of the user's need and make continuous efforts in improving their financial services to their customers. This is the major determinant in the success of these companies. The consumer-centric approach helps the industry to make their products and services easy to access, and convenient to use.

\subsubsection{Single platform for all}

[21]Customers or the users want that they can avail many services on one platform conveniently. Most of the fintech companies have realized this need and had worked upon it which is another reason for its growth as well as gained the trust of the users. 


\subsubsection{Demographics}

As per the reports of "Banking on the future ",2017, As per the report, Gen Y i.e. Millennials is the largest generation who are more digitalized than any other generation and this contributes more to the success of the Fintech industry.

\subsubsection{More and More investments}

As per the reports of "Banking on the future ",2017, There have been more and more investments in technology-based startups since the dot-com bubble of the 1990s.

\subsubsection{Distrust in the banking system}

As per the reports of "Banking on the future ",2017, Global Financial Crisis that has been raised during 2008, lowered the trust of the public in the banking system and gained the trust of Fintech on the other hand.

\subsubsection{Ripening of e-commerce}

As per the reports of "Banking on the future ",2017, Fintech has been geared by the intensive growth of e-commerce in the countries where there is less use of credit cards or the major section of the society is unbanked. According to the latest reports published by Invest India(National Investment Promotion \& Facilitation Agency Factors responsible for the growth of WealthTech Industry in India: Growth of personal wealth, Improvement in communication and sharing of the information $b / w$ various financial institutions as well as investors, Rapid adoption of mobile technology along with other digital platforms.[21]The rise of e-commerce customers, rising trust over fintech services, the impact of the global pandemic, emergence of cashless economy, decreasing usage of debit/credit cards, etc. are the reasons that made the future of fintech firms more bright.[2]Many factors become the reason for the innovation in the financial services sector. Globalization, less intervention in the working of financial markets, high competitiveness, advancement in the technology to name a few. Fintech in the banking sector has changed the work perform by traditional banks. Now banks are partnering with the fintech companies to reduce competitiveness and simultaneously to gain the benefit of technology. Smart devices are being used along with debit/credit cards which further became the reason for the growth of Fintech. Government initiatives such as Adhaar linking, Jan Dhan Yojana, Cashless Digital Transactions, etc. have fueled this Fintech sector which will be expected to flourish more in the coming future. [18]

\subsection{Statistical Reports on Fintech \& its future avenues}

[21] enlightened that the Fintech industry in India is going through many changes and it is one of the booming industries in upcoming years since many sectors are adopting Fintech at a very fast rate due to the pandemic which had occurred in 2020. India accounted for $87 \%$ of the worldwide fintech adoption rate by March 2020. According to the latest reports published by Invest India(National Investment Promotion \& Facilitation Agency Fintech software market size is approx. $\$ 2.4 \mathrm{bn}$, Fintech investments are approx. $\$ 5.7 \mathrm{bn}$, Payments through UPI digitally reached up to $\$ 14.1 \mathrm{bn}$, Highest expected ROI on Fintech projects is $29 \%$ (globally). The digital payment segment has been considered as the main promoter of Fintech. India had launched "IMPS"(FIRST REAL-TIME PAYMENTS SYSTEMS) \& UPI in the year 2010 \&2016 respectively and till now we are having around 375 payments startups. There will be a rapid increase over online transactions approximately around $\$ 12.4$ globally by 2025 POS/mobile POS, Mobile / digital wallets, 
and many other sub-segments accounted for about $50 \%$ of payment startups in the country and it has been targeted to contribute $2.2 \%$ towards the market of digital payment by 2023. In promoting the lending segment, the urban population plays a vital role as they want to avoid many formalities of documentation, rural population, on the other hand, benefitted from this lending. Coming towards Insurtech, so there are more than 110 such types of startups currently operating in the country. According to the latest reports published by Invest India(National Investment Promotion \& Facilitation Agency), there is a large number of Adhaar formation which accounts for about 1.2bn enrolments, there is continuous Encouragement of government initiative of Jan Dhan Yojana that accounts up to $1+$ bn bank accounts, continuous increment in the number of smartphones users accounting for about 1.2 bn mobile phone subscribers, APIs setting up for various startups and businesses, Government initiatives such as UPI \& digital India increased disposable income. It is been estimated that India will be able to include $140 \mathrm{mn}$ as income from the middle class as well as $21 \mathrm{mn}$ from the side of the high-income class by 2030 , because of the expansion in the middle class and this will further become the reason for the massive growth of Indian Fintech.

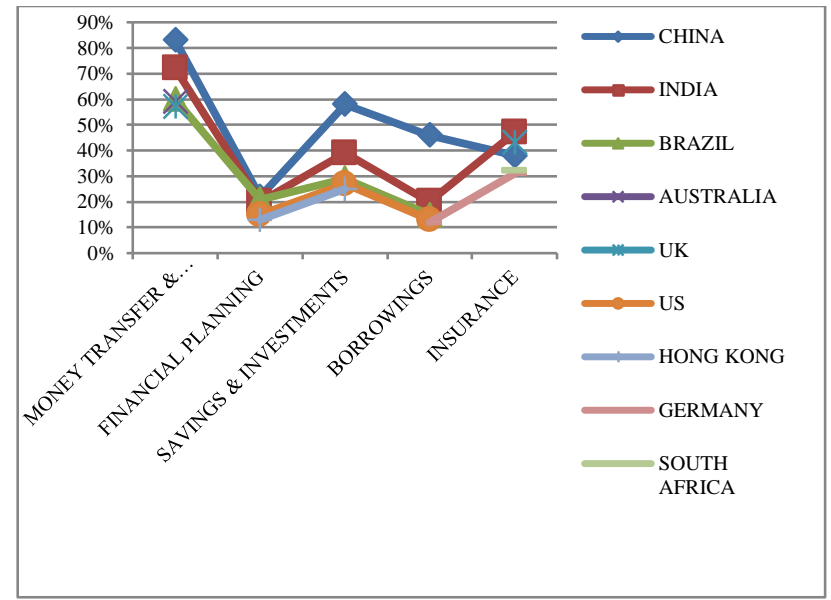

Figure 1

The top 5 markets of Fintech Adoption have been compared with respect to the adoption rate in different segments of the Fintech industry. This has been shown with the help of the following figure.

\section{Source: EY FinTech Adoption Index(2017)}

\section{Compiled by the author}

To compare the FinTech adoption rate among the top 5 countries, 5 segments of the Fintech industry have been taken i.e. money $t / f$ and payments, financial planning, savings and investments, borrowings, and insurance. China has max. adoption rate in the first four categories with $83 \%, 22 \%, 58 \%, 46 \%$ respectively. While it is in the third position with the adoption rate of $38 \%$ in the category of insurance after India(highest; $47 \%$ ) and UK(43\%). India has topped in the insurance category while it is in the second position concerning the category first, third, and fourth with the adoption rates of $72 \%, 39 \%, 20 \%$ respectively. 
It has secured the third position in the second category with the rate of $20 \%$ after China $(22 \%)$ and Brazil(21\%). Brazil is in the third position with the adoption rate of $60 \%, 29 \%, 15 \%$ in category first, third and fourth respectively while it has achieved $2^{\text {nd }}$ position in the $2^{\text {nd }}$ category with the adoption rate of $21 \%$ after China.

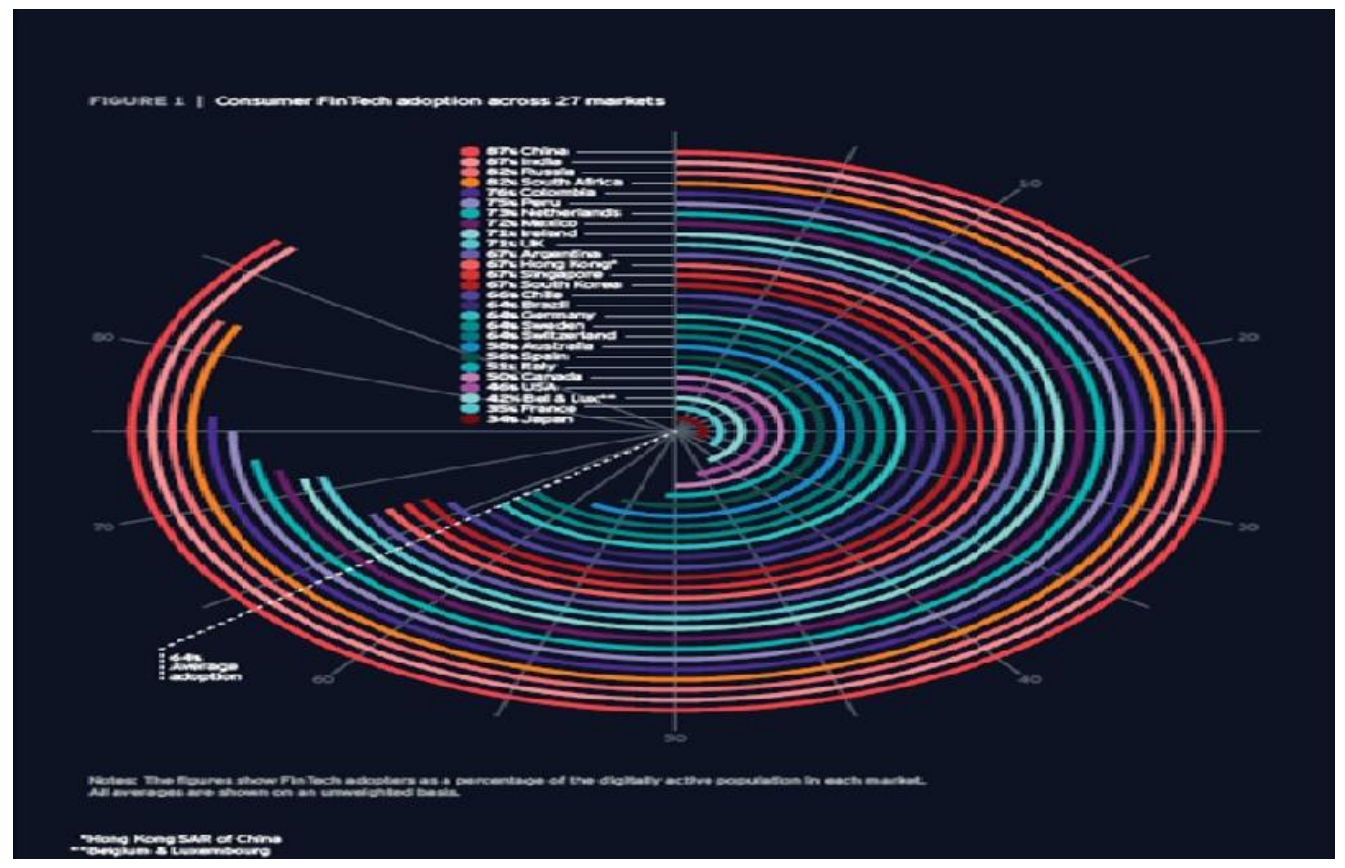

Figure 2

\section{Rate of adoption of Fintech across the 27 countries}

\section{Source: EY Global FinTech Adoption Index (2019)}

The above figure depicts the percentage of Fintech adopters among the crowd which is digitally active. The average adoption rate is $64 \%$ in 2019 which was 33\% in 2017. It is evident from the figure that the highest adoption rate is in China(87\%) as well as in India $(87 \%)$ which indicates that Fintech in India is a booming industry that has already gained the trust of the users with regards to the getting customized and secured services along with the best quality products. As per the reports of 2019, the Fintech adoption rate in the category of money transfer and payments is $99.5 \%$ in both the countries namely India and Russia which was 72\% in 2017 in the case of India. Change in the government plans to decrease the flow of paper money in the Indian market, is the major cause for this growth in the adoption percentage in India. 


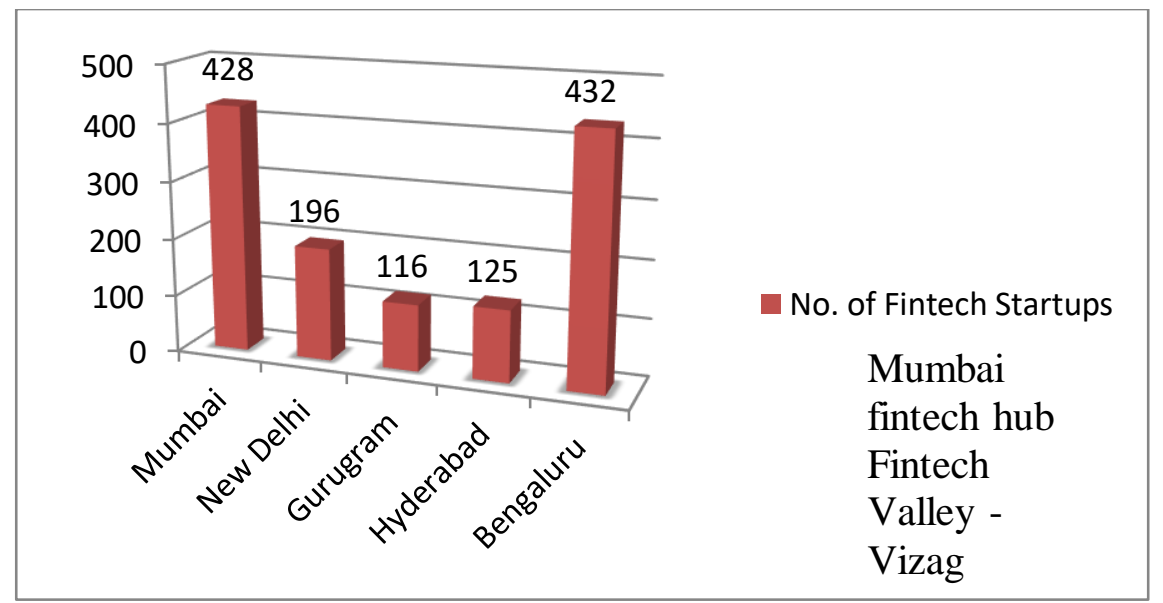

Figure 3

The above fig. is depicting the no. of fintech startups and the fintech hubs in India

\section{Source: https://www.investindia.gov.in/}

\section{(Data has been compiled by the author)}

It has been clearly understood from the above figure that there are 428 Fintech startups in Mumbai,196 in New Delhi, 116 in Gurugram, 125 in Hyderabad, and 432 Fintech startups are based in Bengaluru. Moreover, Mumbai and Vizag are the Fintech Hubs in India.

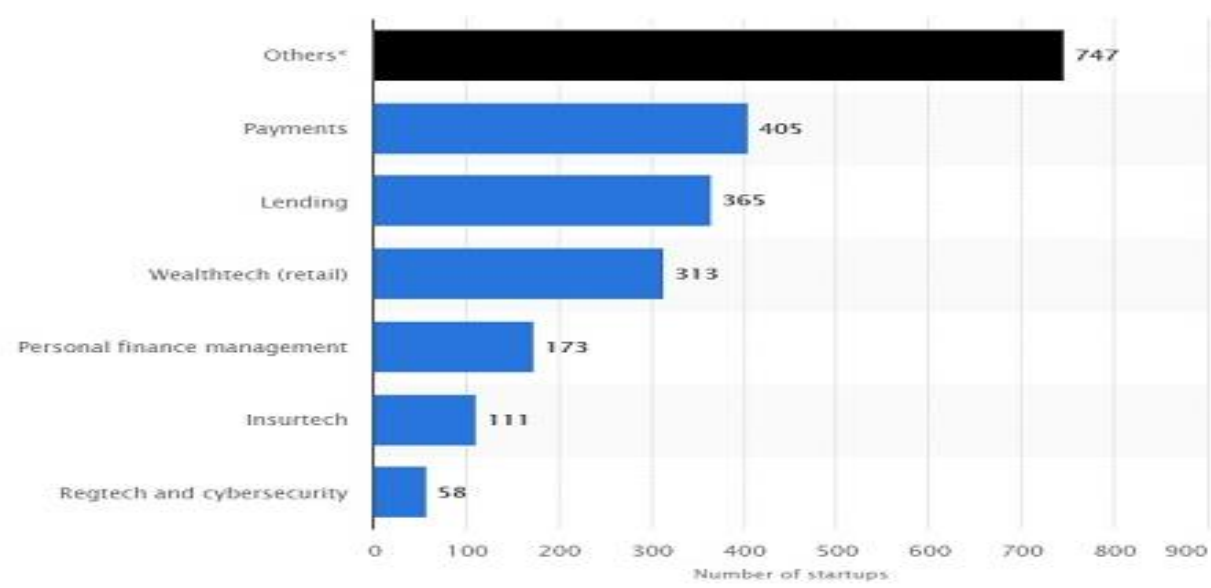

Figure 4

\section{Source:statista.com}

The above fig. shows the number of startups in India in different sectors of Fintech during 2020. It has been clearly visible that the payment sector has the much more potential of growth and development as compared to another sectors. 


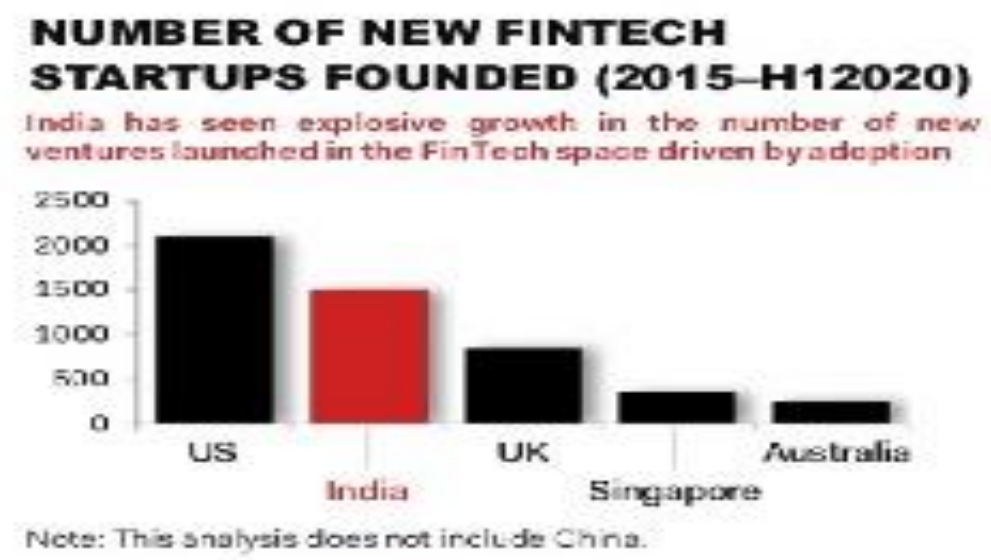

Figure 5

Source: https://gomedici.com/research-categories/india-fintech-report-2020

India has occupied a second place when its come to the emergence of new fintech startups in between 2015 - 2020 after US. It is evident from the report published by MEDICI.

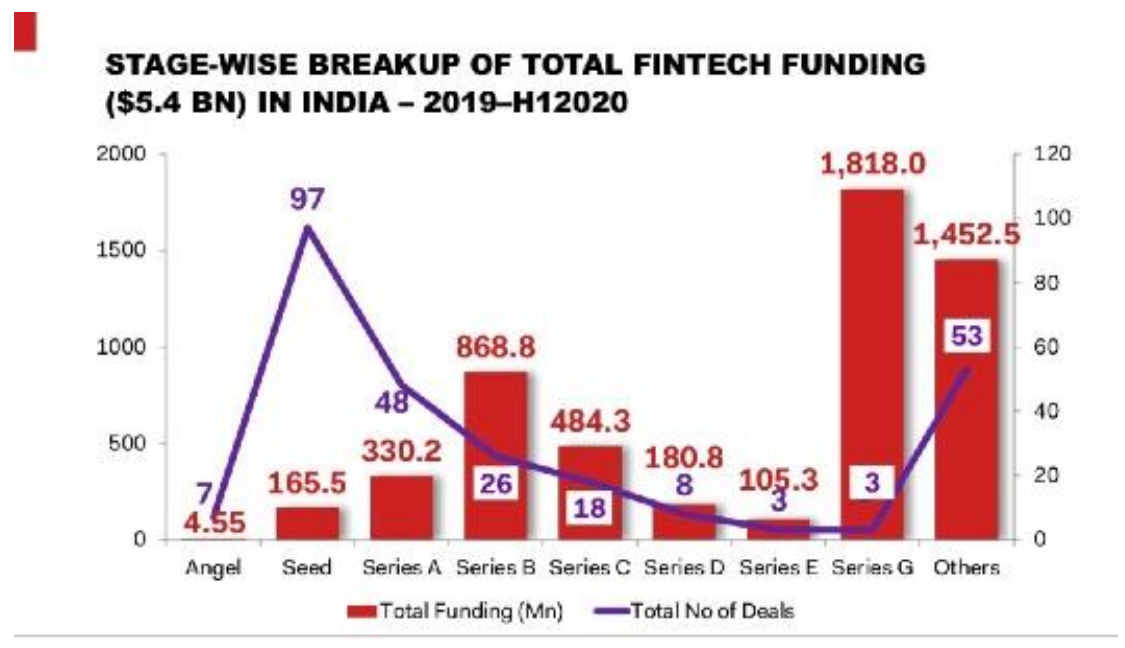

Figure 6

Source: https://gomedici.com/research-categories/india-fintech-report-2020

Fintech startups are booming in India and this has been depicted by the above fig. There has been tremendous investments in the Fintech sector. 


\section{Research Methodology}

This study is being conducted based on the data which has been published in the reports of EY FinTech Adoption Index 2017 and 2019. Many of the case studies, review articles, conferences as well as research articles have been studied along with other secondary sources to write this research paper. The data has been collected from different relevant sites such as google scholar, ResearchGate, Web of science, Elsevier, Springer journals, which are the trustworthy platforms for the collection of the original work of the researchers and academicians. Data has been collected from the official website of RBI which has given the proper statistics related to Fintech. Different studies which have been conducted on Fintech have been analysed. Different studies based on FinTech, internet finance, digital finance, inclusive finance, rural finance, and financial inclusion are centralized here. Besides, some articles were collected from the World Bank database, which is regarded as one of the best databases for financial inclusion research. 


\section{Conclusion}

From the above discussion on the Fintech scenario in India, it has been concluded that this segment has immense potential for further growth. There is no doubt that this sector is nascent or at the early stage but is growing at a very high speed as it is supported by the government in many ways. [21] Fintech will expand to a great extent as it is doing its job as per its objectives to provide the consumers digital financial services at their ease which they can afford. Data analytics on the other hand helps the industry to connect with the customer needs more deeply which in turn paved the way for the more customized provision of the services. The banking industry continuously making changes as per the needs of the users. The payment sector has revolutionized with the advent of Fintech. According to EY Fintech Adoption Index 2017, It has been concluded in the report that the Fintech industry is not only providing the users with new products or services but it is molding the existing products and services as per the needs of the consumers to fulfill their demands as well as to quench their thirst of satisfaction. Moreover, the fintech industry is achieving more customer traction in the banking field than in insurance and wealth management thereby disrupting the traditional customer relationship. Newly formed tech startups are getting successful as the expectations of the masses are rising. Established firms are also getting into the partnership with the fintech firms to satisfy their customers with the qualitative products and services at low cost[21].As per the article published in Financial Express, There are more than $500 \mathrm{M}$ internet users in India and approx. 95\% of them use mobile phones to transact over the internet. Fintech has arrived in the market in the form of partnership between the traditional financial service institutions and the more competitive, emerging, and dynamic Fintech firms.82\% of traditional organizations are feared about their setback from the market in the coming years therefore they have started partnering with the dynamic ones to be in the race. New fintech firms are providing user-friendly services to their customers in terms of lending, investments, spending, transfer of funds, etc. Another feature of these Fintech firms is that they are helping e-commerce and that too on the existing B2B, B2C platforms. So, these firms are fully prepared to serve their users after lockdown and postpandemic.[17]According to this study, traditional institutions that are working in the field of finance, will not be able to cater the needs of their clients because of the rapid growth of the fintech services. [9] As per the article in the Financial Express, it has been forecasted that there will be the tremendous collaborations among the traditional as well as fintech co.s which accounts for around $82 \%$. This will further increase in the coming three to five years. 


\section{Acknowledgement}

This work is purely an original work. I would like to extend my heartfelt gratitude towards my Research Guide Prof.(Dr.)Pankaj Madan for his ever ready support, guidance and continuous motivation throughout the journey. Without his help this work has never been accomplished. I am thankful to my parents who have always supported me in my work by their moral support, financial support. I would also like to thank the whole team of Gurukul kangri (deemed to be university) for providing me the required internet access as well as the facility of library. Last but not the least, I would extend my thanks to my co scholars for their wonderful support.

\section{Funding}

This research did not receive any specific grant from funding agencies in the public, commercial, or not-for-profit sectors. 


\section{References}

[1]Ernst \& Young. (2015). EY FinTech Adoption Index 2015. Retrieved from http://www.ey.com/GL/en/Industries/\%0AFinancial-Services/ey-FinTech-adoption-index.

[2]Nair, V. M., \& Menon, D. G. (2017). Fin Tech firms- A new challenge to Traditional Banks: A Review. International Journal of Applied Business and Economic Research, 15(Special Issue), 173-184.

[3]RBSA Advisors. (2021). FinTech Industry in India.

[4]Statista Research Department. (2021). Number of fntech startups in India by segment 2020.

[5]https://www.statista.com/statistics/1013812/india-?ntech-startup-numbers-by

segment/\%0ANumber.

[6]Mankotia, A. (2021). BFSI - Fintech \& Financial Services India - A global FinTech Superpower. https://www.investindia.gov.in/sector/bfsi-fintech-financial-

[7]KAGAN, J. (2020). Financial Technology (FinTech). Investopedia.

[8]https://www.investopedia.com/terms/fintech.asp.

[9]N, R. (2021, December). Fintech in 2021: How fintech will evolve over 3-5 years. Financial

Express, 8. https://www.financialexpress.com/industry/fintech-in-2021-how-fintech-will-evolveover-3-5years/2158524/.

[10]Fintech Trends Report India 2017. (2013). In Startupbootcamp Fintech (Vol. 53, Issue 9). https://www.startupbootcamp.org/blog/2017/07/fintech-india-trends-report-2017/.

[11]IAMAI. (2017). FinTech in India Ready for breakout. https://www2.deloitte.com/in/en/pages/financialservices/articles/fintech-india-ready-for-breakout.html.

[12]Banking On The Future:An Exploration Of Fintech And The Consumer Interest. (2017). https://www.consumersinternational.org/media/154710/banking-on-the-future-full-report.pdf.

[13] Das, S. R. (2019). The future of fintech. Financial Management, 48(4), 981-1007.

[14]Customers International. (2017). Banking on the future :An exploration of fintech and the consumer interest. Finance and Development, 24-25. https://www.consumersinternational.org/media/154710/banking-on-the-future-full-report.pdf.

[15]Global FinTech Adoption Index 2019. (2019). https://assets.ey.com/content/dam/ey-sites/eycom/en_gl/topics/financial-services/ey-global-fintech-adoption-index-2019.pdf?download.

[16]Ernst \& Young. (2017). EY FinTech Adoption Index 2017. http://www.ey.com/GL/en/Industries/\%0AFinancial-Services/ey-FinTech-adoption-index.

[17]Parameshwar, H. S., Sruthie, A., Cisse, M., Ajay Kumar, M., \& Misra, S. (2019). Fintech and disruptions: An impact assessment. Journal of Critical Reviews, 6(6), 89-97. https://doi.org/10.22159/jcr.06.06.13.

[18] Vija, C., Rajeswari, P., \& Vijai, C. (2021). Fintech Industry In India: The Revolutionized Finance Sector. European Journal of Molecular \& Clinical Medicine, 7(11), 4300-4306.

[19]Mention, A. L. (2019). The future of fintech.

[20] RBI. (n.d.). FinTech. https://www.rbi.org.in/Scripts/BS_fintech.aspx.

[21]Sharma, N. (2021). Fintech Trends Making Waves In 2020 and Outlook For the Industry In 2021. https://www.entrepreneur.com/article/364221.

[22]Chandwani, S. (2020). Fintech In India : An Analysis Of Current Legislation And What Lies Ahead? 
Inc42.Com.

[23]Chugh, B. (2019). Financial Regulation of Consumer - $f$ acing Fintech in India : Status $Q$ uo and Emerging Concerns (WP-2019-01).

[24] Kavuri, A. S., \& Milne, A. (2019). FinTech and the future of financial services: What are the research gaps?. 